Corporation. In order to cover the greatest possible area in the central and southern portions of the North of England, the site of the Holme Moss station was chosen in a very high and isolated region some sixteen miles east-north-east of Manchester. The altitude of the site is $1,700 \mathrm{ft}$.; and this, with the mast, which is similar to that of the station at Sutton Coldfield, Birmingham, results in the height of the aerial being some $2,450 \mathrm{ft}$. above sea-level. The carrier frequencies of the vision and sound transmitters are 51.75 and $48.25 \mathrm{Mc}$./s., and the corresponding powers are 45 and $12 \mathrm{~kW}$., respectively. The resulting range for good and reliable reception is expected to be between fifty and seventy miles, depending upon local conditions and the nature of the intervening terrain. It has already been reported that the opening programme was received clearly in North Wales at a distance of about eighty miles.

Due to the exposed position, special precautions have been taken in the design of the buildings and the mast to ensure that they will stand up to the severe blizzards and gales which will almost certainly be experienced during most winters. The task of maintaining and operating the station will not be easy or pleasant; and arrangements have been made for the staff to live on the station when access becomes difficult or impossible owing to snow and ice. The Holme Moss transmitter is connected to the Birmingham and London television stations by a special coaxial cable installed by the General Post Office. This cable transmits programmes in either direction as required; and it provided a very satisfactory means of viewing, in the London area, the inaugural ceremony of the new station in the Manchester Town Hall, and a programme from the Theatre Royal, Leeds, on the following evening.

\section{Thousandth Issue of The Practitioner}

FInst published in 1868, The Practitioner has celebrated its thousandth issue (vol. 167, October 1951), providing, in addition to its usual features, thirteen valuable articles on advances in various aspects of medicine and surgery. All these articles are written by distinguished specialists in the fields they cover. There is also an article by Sir Henry Dale entitled "The Changing Face of Medicine, 1868-1951", another by Sir Henry Bashford on "The Social Background of Medicine" and a third by Dr. W. N. Pickles entitled "Trends of General Practice: a Hundred Years in a Yorkshire Dale". The whole issue thus constitutes an epitome of the immense advances that have been made in the past hundred years or so, and it worthily enshrines the very great benefits that medicine has conferred upon us during this period. In these benefits the animals, especially the domesticated animals, have shared, and one of the inspiring trends, not specifically noticed in these pages, is the increasing co-operation between the medical and veterinary professions. It is impossible to select from so many excellent articles any that are more valuable than the others. The layman will find a great deal that will interest and encourage him in the three papers already mentioned; Dr. Pickles, in his sketch of three generations of practitioners, re-creates for us that great and tireless 'guide, philosopher and friend', the general practitioner of an age that many readers will know only in literature. The Practitioner has proved, with this issue, that it is as vigorous and progressive as it has ever been, and it would not be easy to find, for any scientific journal, contributors more skilled in the art of explaining, pleasantly and effectively, the intricate matters that are the busy medical practitioner's everyday concern.

\section{Institute of Metal Finishing}

THE Council of the Electrodepositors' Technical Sociéty announces that application for official incorporation has now been granted; also permission has been given for the adoption of a new title embracing metal finishing generally (excluding only vitreous enamelling). This is in accordance with the general policy of the Society to extend its field beyond electrodeposition processes to include metal finishing generally, with which the bulk of its members are vitally concerned. The new title by which the Society will henceforth be known is 'The Institute of Metal Finishing incorporating Electrodepositors' Technical Society Limited'. The original aims and objects of the Society, namely, to promote the study of, and disseminate information on, electrodeposition and cognate processes as widely as possible, are in no w ay affected by these changes. The sphere of interest. has now been significantly widened and the Council is of the opinion that this will bring with it corresponding benefit to the membership. The executive officers and Council of the Electrodepositors' Technical Society have become the officers of the new Institute. The present executive officers are: President, Mr. H. Silman; Honorary Secretary, Dr. S. Wernick; and Henorary Treasurer, Mr. F. L. James. The headquarters of the Institute are at the Northampton Polytechnic, St. John Street, London, E.C.1 ; all communications should be addressed to the Honorary Secretary at 27 Islington High Street, London, N.l.

\section{Agricultural Research Council: Potato Genetics Station}

T'He Commonwealth Potato Collection, Huntingdon Road, Cambridge, which was formerly a responsibility of the Commonwealth Agricultural Bureaux, has recently been transferred by agreement to the control of the Agricultural Research Council and will in future be known as the Potato Genetics Station. In 1939 the Commonwealth Agricultural Bureaux organized an expedition to Mexico and South America to collect varieties of wild and cultivated potatoes in their native home; and the collection based on the samples brought back has been housed since 1945 in a building erected, through the generous financial assistance of the Nuffield Foundation, on a site provided free of cost by the University of Cambridge. In the past ten years, description and classification of the collection have been completed, and the reactions of the material to certain virus diseases, eelworm, late blight, wart, frost and other factors have been studied. Some work on the chemical content of tubers has been carried out, but much remains to be done. This comprehensive collection would seem to offer valuable material for comparative biochemical studies in a vegetatively propagated crop plant. Students in several Commonwealth countries co-operated in this first phase of the work, and material has been widely distributed for the use of potato breeders at home and overseas.

The change in administrative responsibility marks the beginning of a second phase of development, in which the collection will be used mainly for genetic research. The programme includes studies of resistance to various diseases, with a view to the synthesis of lines for the potato breeder, and investigation of 